n. ${ }^{\circ} 1$

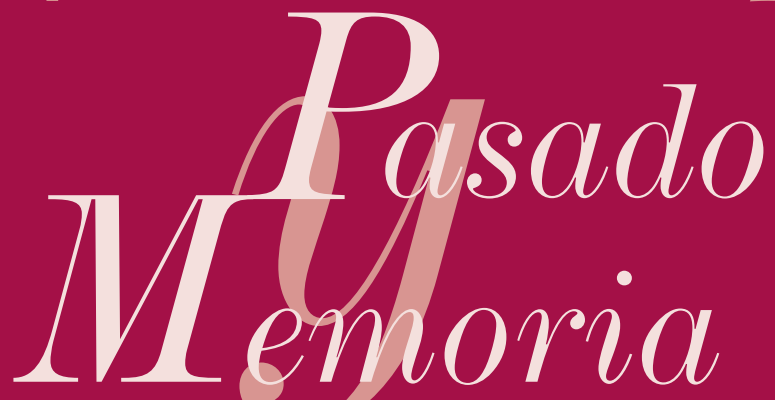

Revista de Historia Contemporánea

Instituciones y sociedad en el franquismo

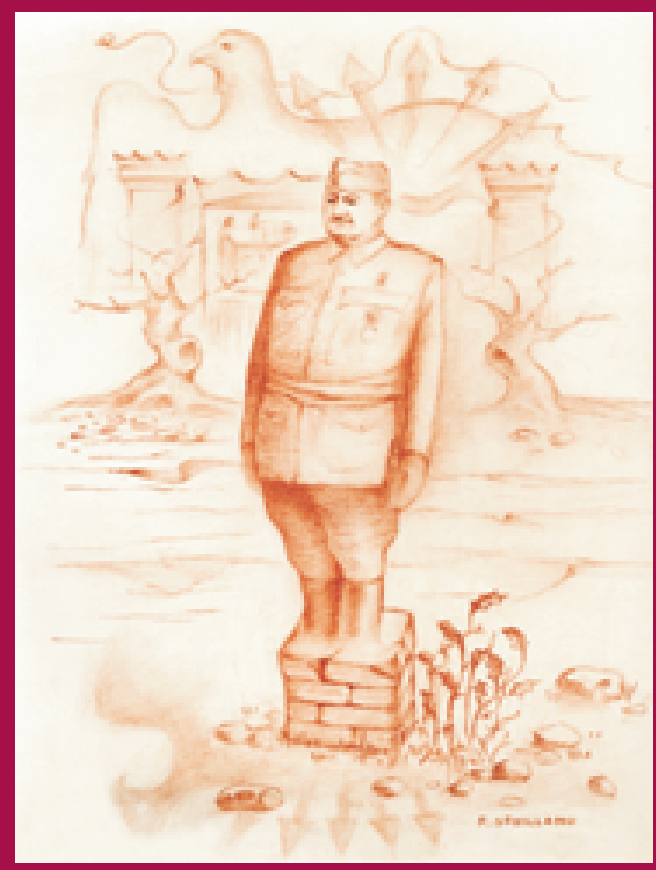




\section{Dirección: Glicerio Sánchez Recio}

Secretaría: Francisco Sevillano Calero

Consejo de redacción: Salvador Forner Muñoz, Rosa Ana Gutiérrez Lloret, Emilio La Parra López, Roque Moreno Fonseret, Mónica Moreno Seco, José Miguel Santacreu Soler, Rafael Zurita Aldeguer

Consejo asesor:
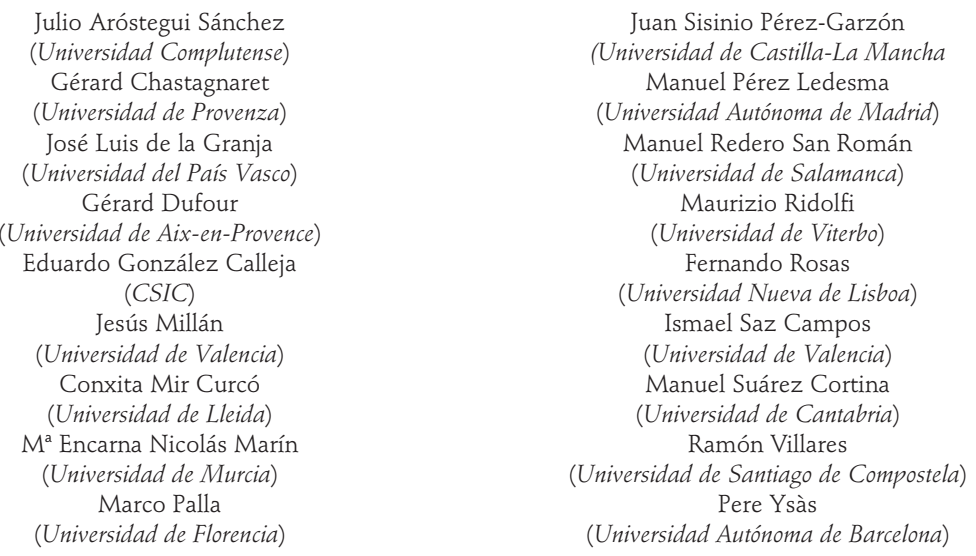

Coordinación del monográfico: Glicerio Sánchez Recio

Ilustración de la portada: El despropósito, por Francisco Sevillano Bonillo

\begin{tabular}{|c|c|c|c|}
\hline Edita: & $\begin{array}{l}\text { Departamento de Humanidades Contemporáneas } \\
\text { Área de Historia Contemporánea } \\
\text { Facultad de Filosofía y Letras } \\
\text { Universidad de Alicante } \\
\text { Apartado Postal } 99 \\
03080 \text { Alicante }\end{array}$ & Distribución: & $\begin{array}{l}\text { Publicaciones } \\
\text { Universidad de Alicante } \\
\text { Apartado Postal } 99 \\
03080 \text { Alicante }\end{array}$ \\
\hline
\end{tabular}

Composición: Espagrafic

Impresión: INGRA Impresores

Depósito legal: A-293-2002

ISSN: 1579-3311

Reservados todos los derechos. No se permite reproducir, almacenar en sistemas de recuperación de la información ni transmitir alguna parte de esta publicación, cualquiera que sea el medio empleado -electrónico, mecánico, fotocopia, grabación, etc.-, sin el permiso previo de los titulares de los derechos de la propiedad intelectual.

\section{Estos créditos pertenecen a la edición impresa de la obra}

Edición electrónica:

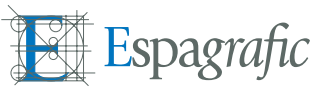




\author{
Jesús Millan \\ Universitat de València
}

\title{
EL “DESASTRE” DEL 98 I LA CRISI SOCIAL DE L'ESTAT LIBERAL ESPANYOL
}


Índice

Portada

Créditos

EL “DESASTRE” DEL 98 I LA CRISI SOCIAL DE

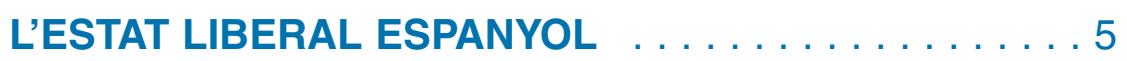

1. Cohesionar políticament el nou ordre social . . . . 10

2. Un ordre socialment nou, però amb efectes polítics paralitzant . . . . . . . . . . 17

3. L'expansió política dels nacionalismes alternatius . . . . . . . . . . . . . . . . 29

4. Conclusió $\ldots \ldots \ldots \ldots \ldots \ldots \ldots \ldots \ldots \ldots$ 


\section{El “desastre” del 98 i la crisi social de l’Estat liberal espanyol}

Jesús Millan

Universitat de València

I text de més impacte les setmanes posteriors a la de-
rrota del 1898 posava en relleu algunes conductes de-
finitòries de la societat espanyola que, a posteriori, només es podien veure com a ominoses. "La guerra con los ingratos hijos de Cuba no movió una sola fibra del sentimiento popular", plantejava obertament aquell article Sin pulso, que aviat es faria famós. La passivitat del país l'havia preparat, afirmava, "para dejarse arrebatar sus hijos y perder sus tesoros". Aquesta indiferència letàrgica garantia l'estabilitat política, però -en opinió de Francisco Silvela, autor del textaquesta era una impressió perillosa: sense una opinió pública activa i vigilant, els grans assumptes d'Estat es transformaven en pura farsa i per aquesta via es marxava directe al fracàs. "Hay que dejar la mentira y desposarse con la verdad 
(...). No hay que fingir arsenales ni astilleros donde sólo hay edificios y plantillas de personal que nada guardan ni nada construyen; no hay que suponer escuadras que no maniobran ni disparan; ni cifrar como ejércitos las meras agrupaciones de mozos sorteables, ni empeñarse en conservar más de lo que podamos administrar sin ficciones desastrosas".

En aquella conjuntura històrica, allò que s'havia tingut pel gran avantatge del règim havia esdevingut un parany insuperable, que abocava al col.lapse de la mateixa societat nacional: "Engañados gravemente vivirán los que crean que por no vocear los republicanos en las ciudades, ni alzarse los carlistas en la montaña (...) nada hay que temer ya de los males interiores que a otras generaciones afligieron (...) El riesgo es el total quebranto de los vínculos nacionales, de la ordenación por nosotros mismos de nuestros destinos como pueblo europeo".

Llavors el diagnòstic podia ser acceptat per molts: a l'època d'una creixent competència internacional en el terreny econòmic i de la política exterior, un Estat-nació políticament estable, però sense la capacitat fiscalitzadora de l'opinió cívica, es veia com un exemple de fracàs col.lectiu. La mateixa faceta que representava l'avantatge més gran del sistema - 


\section{El "desastre" del 98 i la crisi social de l'Estat liberal espanyol}

l'estabilitat política de la Restauració- era l'altra cara d'una moneda que, ara, mostrava l'espectre d'un inaplaçable fracàs com a nació.

Com es va arribar a aquest "clima" intel.lectual i polític del 1898 ? L'any del "desastre" ha estat de fet la cruïlla d'un canvi de tendència a l'Espanya contemporània. Sovint ha estat a partir d'ell com s'ha avaluat el camí recorregut abans. Alhora, a partir d'ell es valora el tomb que anirà cristalitzant en les dècades successives, quan el perllongat liberalisme de la Restauració s'anirà esvaïnt en favor d'una dreta autoritària i, des de la dictadura de Primo de Rivera, receptiva al feixisme. D'una banda, les tesis historiogràfiques més perllongades fins ara consideraven en gran mesura normal el "doble fracàs de l'Estat i de la nació" a l'Espanya de 1898.

Des de posicions diverses, la línea argumental era coincident. L'Estat-nació espanyol s'havia bastit al segle XIX a partir d'una revolució liberal que hauria renovat molt poc les estructures socials, que serien igualment o més intensament oligàrquiques que sota l'Antic Règim. La hipòtesi de l'anomenada "via prussiana" -la suposada transformació dels senyors en propietaris latifundistes, tan divulgada pel regeneracionisme, el republicanisme conservador o el marxisme d'una època-, la d'un sòlid "bloc de poder" agrari i financer ca- 
paç de determinar els poders de l'Estat, la insistència en el caràcter rural de les estructures i dels valors socials o l'accentuació d'un centralisme basat en la intensa militarització de l'ordre públic condueixen a un panorama semblant. EI precoç liberalisme espanyol del segle XIX seria un factor més aviat superficial o, en tot cas, massa condicionat pel seu caràcter burgès i oligàrquic com per a projectar una imatge participativa, mobilitzadora o capaç de "nacionalitzar les masses". Lògicament, el consens oligàrquic de la Restauració només podria recolzar en una façana liberal, no democràtica i cada cop més ineficaç i carrinclona, com denunciava Silvela.

En els darrers temps, els balanços globals han pres en compte els resultats d'alguns camps de la investigació -com ara, determinats aspectes de la història econòmica de l'Espanya del canvi de segle- i, per tant, han modificat el panorama de l'època del "desastre". Això s'ha fet sobretot a partir de la perspectiva de la teoria de la modernització. Des d'aquest punt de mira, és la trajectòria a llarg termini allò que orienta l'anàlisi històrica. La sòlida comprovació d'un fil de creixement econòmic i de la urbanització de la societat espanyola fa relativitzar molt el clima de pessimisme que es desfermà arran de la primavera del 98. La desfeta colonial, 


\section{El "desastre" del 98 i la crisi social de l'Estat liberal espanyol}

és cert, no va impedir l'empenta econòmica que es comprova en el canvi de segle. A partir d'aquesta comprovació ha estat fàcil concloure que la crisi del sistema polític formaria part d'un problema parcial, que només acabaria absorbint-se temps a venir, un cop salvat el doble i perllongat parèntesi dictatorial del segle XX. D'aquesta manera, s'ha anunciat precisament per part d'alguns representants de la tesi del fracàs del liberalisme espanyol, la història de l'Espanya contemporània seria un cas més d'un país "normal". Aquesta tesi no ha aprofundit gaire en les implicacions d'aquesta "normalitat" i, fins ara, tampoc no ha revisat la imatge convencional de la formació de l'Estat eixit de la revolució liberal. Ara, la crisi del 98 se situa sobretot en la perspectiva de la seua posterioritat a llarg termini, on l'Espanya integrada en les institucions europees i atlàntiques del postfranquisme marca les pautes interpretatives del passat.

Al meu entendre, aquesta perspectiva és font d'un bon nombre de problemes malament resolts, com ara els que deriven d'un considerable esquematisme i d'una bona dosi de teleologia. Si volem entendre el clima que s'instal.là a partir de 1898 com a alguna cosa més que un desajustament transitori dins d'una seqüència "normal" -hi ha alguna que no ho siga a llarg termini?-, aleshores caldrà prendre com a punt de 
referència no algun suposat "final de la història", sinó els processos que havien portat al temps del "desastre" i aquelles evolucions que els seus coetanis podien tenir com a punt de referència.

De cara a l'anàlisi històrica, hi ha dos factors que em semblen d'una gran importància en el panorama de la investigació sobre l'Espanya del vuit-cents. Alhora, tots dos funcionen sobre un teló de fons problemàtic. Els dos grans factors que presenta, amb desigual intensitat, la recerca són la configuració de les jerarquies de la societat espanyola arran del triomf liberal, d'una banda, i la peculiar evolució de l'”espai públic" al llarg de la centúria, d'una altra. El rerefons problemàtic en el qual s'inscriuen tots dos processos és la formació d'un Estat nacional espanyol, el seu grau de cohesió i d'obtenció de consens social.

\section{Cohesionar políticament el nou ordre social}

A hores d'ara, malgrat que alguns estudis s'estimen sobretot enfocar en exclusiva els aspectes continuïstes respecte a les jerarquies de l'antic règim, aquesta imatge resulta clarament unilateral. La revolució liberal, com es comprova quan se'n fa un balanç comprensiu, tingué l'efecte de configurar d'una altra manera les jerarquies influents a la societat. 


\section{El "desastre" del 98 i la crisi social de l'Estat liberal espanyol}

Això, és clar, no es pot entendre en el sentit d'un canvi radical del tipus de societat anterior, entesa com a un sistema, a la manera dels vells enfocaments que l'assimilaven amb el pas del feudalisme al capitalisme. No entendre la revolució com el fet que va capgirar tot un model nítid de societat no implica negar l'important abast social d'aquell decisiu tall polític. Obliga, però, a definir-lo d'una manera distinta al suposat canvi del mode de producció. El triomf liberal va actuar sobre unes societats complexes i dinàmiques, on coexistien i es combinaven formes d'explotació i estratègies de promoció social, que tant es definien per l'ús del privilegi i el poder senyorial com per la intensificació de la propietat privada i la contractació en el mercat. L'anàlisi històrica practica un reduccionisme estèril si examina les conseqüències del canvi revolucionari sota el prisma de classes socials "pures", configurades de bestreta per l'ús de mecanismes d'explotació de tipus feudal o l'aspiració prèvia a imposar un "model" capitalista. De manera molt variable, però alhora ben estesa, amplis sectors socials recolzaven en una combinació d'elements que, més tard, es codificarien com a part de "sistemes" diferents 0 , fins i tot, oposats.

La revolució liberal va operar aquesta separació, en eliminar tot un seguit d'elements que s'oposaven, com passava amb 
les jurisdiccions senyorials, a la unitat del nou concepte de poder sobirà de l'Estat o que tropessaven amb el principi de la igualtat davant la llei, com era el cas de l'exempció fiscal i legal dels privilegiats. Aquest procés va anar acompanyat, com s'esdevingué a França i Itàlia però en contrast amb els casos d'Anglaterra i Alemanya, per una marcada prioritat per la inversió de fortunes en l'agricultura. Això, en un ambient majoritàriament optimista pel que fa a l'espontaneïtat del desenvolupament econòmic, va provocar una intensa i precoç mercantilització de la propietat agrària, acompanyada del dràstic final dels delmes (que, a més de nodrir l'Església, eren una font clau d'ingressos per a molts senyors i per a l'Estat).

Inevitablement, tota l'operació tenia conseqüències polítiques directes en la vida quotidiana. Molts propietaris arrecerats en el món del privilegi de feia temps van perdre, tot d'una, els avantatges fiscals i la posició que els donaven els vincles i els càrrecs municipals vitalicis o hereditaris. El trasbals, doncs, afectava des dels nivells econòmics fins a la visió d'un ordre suposadament harmoniós i a estalvi de la subversió.

Aquest conjunt de reformes obria possibilitats d'ascens social especialment novedoses, que s'allunyaven dels mecanismes graduals que s'oferien sota l'antic règim. 


\section{El "desastre" del 98 i la crisi social de l'Estat liberal espanyol}

Naturalment, no podien ser igualment aprofitades per tothom. Obrien el camí, doncs, per a una renovació de les jerarquies socials, a partir de la riquesa i la influència que ella generava. Aquesta renovació va nodrir una important i duradora esquerda a l'Espanya del segle XIX, justament perquè els perfils de la transformació duta a terme no eren inequívocs. No era gens evident per a tothom que el que es féu a la primera meitat del vuit-cents a Espanya fos una operació clarament "antifeudal", adreçada a eliminar només institucions obertament obsoletes. Justament això reforçava l'entitat de la querella i la seua projecció per al futur. Convé subratllar que la defensa antiliberal de l'antic règim no es va adscriure a la reivindicació estreta del poder dels senyors o l'Església. L'eix retòricament invocat pels moviments contraris al liberalisme recolzava més aviat, de manera explícita, en la combinació de noblesa, Església i grans propietaris, amalgama social que va mostrar capacitat mobilitzadora a determinats indrets. Des del P. Alvarado, ja a l'època de les Corts de Cadis, fins al carlí fra Magí Ferrer, en la dècada de 1840, l'absolutisme reial es veia com la fòrmula política millor per tal de defensar un ordre just i estable, sostingut per la integració d'eclesiàstics, nobles i grans propietaris, sobretot els ben establerts abans del trasbals promogut per la revolució. Aviat, de fet, s'alçaren veus que rebutjaren el que considera- 
ven l'alteració il.legítima de moltes categories respectables. Pot ser-ne un exemple l'opinió del marqués de Valle Santoro quan, en la dècada de 1830, considerava que la sobirania residia en realitat en la propietat particular, la qual estaria protegida per "la ley sabia e indispensable de la prescripción". De pas, anunciava que un règim que no respectava la propietat existent en un moment donat feia el major dels danys possibles contra el progrés econòmic en el futur.

La intensa remodelació de la societat de l'Espanya liberal quedava, per tant, sota el foc dels arguments que molt d'hora havia avançat el liberal Edmund Burke contra la Revolució francesa. En el moment del "desastre" del 98 encara estava recent la condemna enèrgica de Menéndez Pelayo -ell mateix Ileial a Cánovas del Castillo-, qui invocava Burke contra "el inmenso latrocinio" desfermat, sucessivament, per Godoy, Mendizábal i Madoz: “¿Qué propiedad colectiva será respetable si esta no lo es? ¿Ni qué propiedad privada pudo tenerse por segura el día que el Gobierno llevó la mano incautadora a los bienes dotales de las esposas de Jesucristo?". Aquesta ombra de deslegitimació no era només retòrica. Com es comprova a diferents llocs, la mena de gent que va aprofitar els canals oberts pel liberalisme, tot identificant-se activament amb ell, va constituir durant dècades o 


\section{El "desastre" del 98 i la crisi social de l'Estat liberal espanyol}

generacions un nucli especialment definible entre el personal polític i en bona part de la vida pública i associativa. El "tancament de files" de les classes propietàries no fou complet ni estable a l'època de la burgesia. Clausurar la revolució no significava tancar còmodament les esquerdes obertes entre els recentment configurats rengles de les "classes mitjanes".

Aquestes divergències socials eren especialment significatives en el panorama de la formació de l'Estat, pel fet que poca cosa aprofitable quedava del vell centralisme heretat de la Monarquia absoluta. Els seus mecanismes bàsics s'havien afonat o havien desaparegut. Des de la dècada de 1840, calia edificar-ne un de nou, sobre el rerefons d'unes capes "respectables" de trajectòries força oposades. Per a un univers ideològic com el de la burgesia del vuit-cents, inclinat a definir de manera única els valors respectables, això era un problema gens secundari. El nou Estat centralista nascut de la revolució havia de recolzar en la col.laboració de grups socials de procedències i orientacions diferents.

De manera reiterada, no fou fàcil definir els límits de les capes respectables, amb capacitat per a intervenir de manera autònoma en la vida política. D'una banda, per a sectors influents la clausura de la revolució feia necessari integrar del tot aquells grups que havien donat suport al carlisme, que 
per a ells eren part integrant de la respectabilitat i del bon criteri burgès. D'altra banda, fins 1875 fou ben important el paper d'una burgesia periòdicament inclinada a agitar el caliu de la politització popular en les seues disputes amb el dirigisme conservador. Entre 1840 i l'assentament de la Restauració aquestes escletxes es van reobrir amb força ara i adès.

El pessimisme del 98 es projectava, doncs, sobre dues dècades en què s'havia assajat una solució aparent a aquest estat de coses. Fou, en efecte, després de liquidar l'experiència revolucionària del Sexenni (1868-1874) quan l'estabilitat política va poder coronar una configuració de la societat espanyola que ja tenia vora un terç de segle. La vida política del torn consagrà l'acceptació de les renovades jerarquies socials i acceptà l'exercici polític del que es deia la seua influència social. El món de la Restauració no recolzava sistemàticament en la mateixa mena de gent que havia dominat el poder durant la major part del regnat d'Isabel II. Quan Cánovas es vantava d'haver restaurat la monarquia amb republicans només exagerava moderadament. En realitat, l'edifici polític traçat pel polític malagueny descansava en el fet de reconèixer posicions molt importants a gent de clara tradició progressista i, fins i tot, republicana. La imatge d'una in- 


\section{El "desastre" del 98 i la crisi social de l'Estat liberal espanyol}

equívoca província rural, com Osca, en mans de la xarxa política d'un republicà, reinstal.lat en el liberalisme oficial, com Gamo; l'ascens a la "tranquil.la" Gandia del liberal Sinibaldo Gutiérrez o un vell feu de carlins i moderats durs, com Oriola, lliurada al domini estable de Ruiz Capdepón -un liberal de l'òrbita de Sagasta i Canalejas- eren indicis d'una àmplia transacció entre àmbits d'influència que, per fi, es reconeixien mútuament.

De la mateixa manera, el sistema no era la reedició d'un caciquisme de patró únic. Amb el temps, la seua pràctica va obrir pas sobretot als polítics professionals, producte de l'habilitat i la qualificació, en detriment del simple protagonisme de la riquesa i els seus ressorts coactius, que es mostraren majoritàriament en retirada des de la reintroducció del sufragi universal masculí, el 1891. De fet, la imbricació amb la tan criticada "vella política" caciquista per part dels interessos més dinàmics del nou capitalisme espanyol va funcionar de manera força eficaç cap al canvi de segle.

\section{Un ordre socialment nou, però amb efectes polítics paralitzant}

Aquesta consolidació política de la nova configuració social nascuda del liberalisme es féu, però, sobre determinades 
premisses pel que fa al desenvolupament de l'opinió pública. Com és sabut, el pluralisme liberal de la Restauració era un pluralisme garantit de bestreta. Descansava en el compromís, escassament liberal, de la renúncia a la competència per l'electorat i a perllongar l'agitació política. Havia de recórrer, de manera més aviat autoritària, al principi de la soberania compartida entre el Rei i unes Corts "fabricades" -allò que sovint incloïa dissuasió i transacció- arran de la convocatòria electoral.

Els gèrmens, ben comprovables, de la politització popular de la primera meitat del segle no es perllongaren a Espanya en la difusió dels ideals cívics i participatius, a l'estil del procés que va erosionar definitivament el poder dels notables a la França de la III República. Però aquest subdesenvolupament tardà de l'espai públic a Espanya no es pot fer descansar en la pervivència de velles i estables influències socials. Altrament, es consolidà amb la col.laboració eficaç de molt bona part dels hereus del progressisme i dels polítics d'arrels socials modestes que, a canvi, s'asseguraven la seua participació efectiva en el poder i en el consens quotidià. Per bé que incloïa alguns elements antiliberals, el règim fundat per Cánovas garantia una dosi innegable de pluralisme, que 


\section{El "desastre" del 98 i la crisi social de l'Estat liberal espanyol}

li va guanyar la col.laboració de molt bona part dels corrents progressistes i democràtics.

Aquesta mena d'entesa per construir el pluralisme polític d'esquena a l'opinió pública no era fill directe del fantasma de la subversió social o, si més no, aquesta no és una fòrmula evident. La generació que va establir el sistema canovista i que encara era al poder el 98 es trobava marcada per l'experiència del que havia estat el Sexenni. Fins i tot més que el risc de trasbals social, el que sembla haver-los marcat és una imatge d'irrefrenable i estèril inestabilitat política i, en especial, el fantasma de descomposició de l'Estat. Aquest era el perill que s'identificava amb els onze mesos de la I República i amb la seua contraposició de projectes d'Estat i l'esclat d'un fum de cantons. Era en aquest clima quan el projecte autoritari del carlisme -i els carlins prou n'eren conscients- havia estat més a prop de fer-se realitat. Probablement, es trobava en joc la capacitat d'autoorganització política de la societat burgesa, sense haver de recórrer a una tutela de signe autoritari que podia tornar a replantejar tot l'edifici social. En aquest sentit, l'estabilitat de l'Estat era percebuda com a un requisit mínim de civilització. Tal vegada, les conseqüències polítiques del Sexenni no estaven sempre marcades per l'experiència del radicalisme social, 
que, tot i fer-se present en alguns moviments (pensem a Andalusia o Alcoi), no va assolir el caràcter de la Comuna de París o no es manifestava de manera palesa a bona part del moviment cantonal. Fos o no acompanyat d'un risc més o menys gran per a l'ordre establert, l'espectre de la descomposició de l'Estat o de la perllongada esterilitat dels governs va semblar intolerable per a amplis sectors burgesos. Per a un polític d'arrels inequívocament liberals, com el jove Antoni Maura, "1873 fue un año tal que si hubieran quedado vivos los testigos presenciales, con ellos solos, mudos, sin que nada dijeran, estaría perpetuamente preservada la nación de nuevos trastornos".

Sota aquestes consideracions, àmpliament compartides des dels conservadors fins a importants sectors del republicanisme, es podia consolidar una mena de pacte de reconeixement mutu de les jerarquies de l'Espanya liberal. A partir d'ací, però, es generava una dinàmica que allunyava l'escenari polític espanyol del d'altres països -com França, Anglaterra o l'Alemanya unificada-, on el desenvolupament agitat de l'opinió pública i l'exercici creixent de la ciutadania acompanyaven el protagonisme de la política de masses des de finals de la dècada de 1880. És en aquest context, derivat dels consensos polítics dominants -i no a partir d'un suposat fruit 


\section{El "desastre" del 98 i la crisi social de l'Estat liberal espanyol}

inevitable del retard de l'evolució social-, on cal situar la denunciada debilitat de la societat civil que es descobria amb alarma a l'Espanya del "desastre".

L'alarma per aquest buit era lògica, d'altra banda. Fou aquella doble dinàmica conflictiva i nacional -si es vol, de classe i d'identificació amb l'Estat nació- allò que permetria absorbir les tensions internes mitjançant el mite de la República, a la França del "sindicalisme revolucionari", o allò que preparà per a la Burgfrieden, la treva dels conflictes domèstics entre 1914 i 1918 l'Alemanya escenari, com cap altre lloc, de la política de la classe obrera. Tampoc es donava ací el grau d'autonomia de la tradició progressista, heretada del Risorgimento per la Itàlia de Giolitti, ni l'opció del catolicisme italià per mobilitzar les seues pròpies forces enfront d'un Estat que no acceptava com a seu. Més de dues dècades després de la Restauració i amb uns quants anys de sufragi masculí, l'Espanya de 1898 mostrava el raquitisme que en aquest terreny assenyalava Silvela i que tothom va acordar de sobte a reconèixer. Com es veuria temps a venir, es tractava d'un fet estable i difícil d'adreçar: l'estiu de 1921 una dramàtica combinació d'ineptituds i conxorxes particulars, cobertes amb una façana patriòtica, conduiria a la inmensa 
tragèdia del Rif, que afavoriria el col.lapse del sistema de la Restauració dos anys més tard.

Més enllà del signe de l'evolució econòmica, la consciència d'aquest rumb s'instal.là sense remei el 1898. Probablement, no era una conseqüència inevitable, com sovint s'ha donat per descomptat, del "retard" econòmic o del pes del món rural. Com mostren els estudis sobre la França meridional a mitjan segle XIX, societats perifèriques, agràries i malament adaptades a la llengua oficial podien experimentar un intens procés de politització i d'adscripció republicana, capaç de retallar la influència dels poderosos tradicionals. En el cas espanyol el mecanisme del torn programat, sense competència per guanyar un electorat real, tenia efectes directes de signe desmobilitzador, reforçats si calia per una concepció militarista de l'ordre públic. N'era un exemple contundent la manca d'iniciativa mobilitzadora dels dos partits del sistema durant els mesos de guerra contra els Estats Units. Els espanyols eren reiteradament convidats, es podria dir, a no exercir com a ciutadans, sinó a delegar en una classe política plural i pactista. L'únic mecanisme de legitimació d'aquesta classe política havia de ser el foment del clientelisme i l'eficàcia en la defensa de reals o imaginaris interessos locals. La identitat castellanista d'Espanya assumida pels canovistes no era 


\section{El "desastre" del 98 i la crisi social de l'Estat liberal espanyol}

només de tipus tradicional i retrospectiu, sinó que posava l'accent en el pessimisme que derivava de la seua visió de la secular decadència espanyola. En el camp dels plantejaments nacionalitzadors -en obert contrast amb la França republicana o l'Alemanya del II Reich-, no tenia gran cosa a oferir aquesta mena de política liberal. L'onada de localisme que es va abatre sobre la política espanyola no es pot atribuir de manera directa a una herència inmòbil del passat. Probablement, era un producte reforçat o induït pels mecanismes polítics que havien consolidat la intensa renovació de la societat espanyola de la segona meitat del vuit-cents.

El consens per a reduir de manera estable el marge de l'opinió pública disposava d'importants precedents. Aquests predisposaven que l'alternativa més fàcil per al col.lapse del liberalisme no democràtic fos un autoritarisme amb escasses arrels populars. El pensament reialista i carlí havia insistit en la tutela de l'opinió pública. Aquest era un criteri al qual es mostraven receptius aquells polítics que podien fer de pont en el projecte de tancar la dramàtica esquerda oberta amb els carlins. Jaume Balmes valorava de manera ben negativa l'autonomia de l'individu respecte a l'autoritat, allò que s'havia introduït a partir de la crisi de l'antic règim. Donoso Cortés, per a qui la llibertat havia fet ja tot el que calia a mit- 
jan dècada de 1840, estava convençut que convenia limitar l'esfera pública a determinats temes i sectors de la bona societat, en absolut identificables amb la generalitat del poble. En cas contrari, si es persistia a tractar els problemes inevitables que afectaven els sectors populars, havia advertit el 1839, s'estava provocant riscos imprevisibles: calia aprofitar el fet que "las muchedumbres duermen todavía el sueño de la inocencia". La perspectiva de Donoso -qui ja havia demanat a Ferran VII que reconegués el pes polític de les "classes mitjanes"- pot representar la de sectors nascuts de la remodelació liberal de la societat. El mateix mostrava la fòrmula d'Alcalá Galiano, el 1843, quan legitimava un poder polític excepcional per tal d'assegurar "las conquistas de la revolución", sobretot quan la inestabilitat política s'imposava i feia impossible el govern d'un Estat de dret.

Sota elements liberals significatius -el pluralisme de l'alternança i el joc d'unes Corts que "compartien" sobirania amb el rei-, la Restauració practicà una reducció de l'àmbit de la ciutadania. Les prevencions contra la figura de la multitud en l'espai públic, l'acord per a esquivar la competència electoral i l'acceptació que les disparitats socials eren una llei natural conduien a reemplaçar la ciutadania pel clientelisme caciquista i la identificació local. 


\section{El "desastre" del 98 i la crisi social de l'Estat liberal espanyol}

Però tot això no es pot atribuir al suposat triomf de les forces conservadores o de l'inmobilisme cultural de la Espanya del vuit-cents. Molt bona part de la tradició progressista i, fins i tot democràtica, del liberalisme espanyol -com prou ho mostren els casos de Sagasta, Moret o Romanones-, van reelaborar ara el seu ideari. Bàsicament, aquesta "esquerra" del règim coincidia en què les fòrmules polítiques liberals consistien sobretot en el pluralisme i l'alternança, elements que sols eren viables a Espanya sota el dirigisme de la classe política i la submissió popular. A efectes pràctis, l'horitzó democràtic se situava sovint en el passat i adquiria entre molts d'ells el caràcter d'un experiment ja gastat. En contrast amb l'antiga perspectiva progressista, ara un especial elitisme polític s'havia consolidat en els sectors liberals del règim, legitimats per la seua conversió al positivisme. Si perillava aquesta premissa, la tradició liberal podia trobar preferible un poder autoritari, sempre que no agranara el conjunt del personal polític establert. Un repàs als cacicats estables, independents del favor del govern, mostra fins a quin punt eren, a principis del segle $\mathrm{XX}$, els segments liberals els que mostraven més habilitat per tal de guanyar el consens oligàrquic i, alhora, els més afectats per una dinàmica que bloquejava l'evolució cap a la democràcia. 
L'acceptació per tots els sectors burgesos de les escales establertes de la desigualtat social -com a un "fet natural i inevitable"- no va fornir llavors tota la cohesió que calia. A llarg termini, l'efecte integrador d'aquest pacte oposat a l'autonomia de l'opinió pública es veié contrarestat per la inhibició induida- de la ciutadania i les seues repercussions negatives sobre la eficàcia de l'Estat en els nous temps de finals de segle. Maura, en una línea comparable al que havia fet anys abans Menéndez Pelayo, reconeixia l'àmplia mobilitat experimentada per la societat espanyola contemporània. "Aquí no hay jerarquías sociales", afirmava pocs anys després del "desastre", "la sociedad española es la más llana, más igual, menos articulada, con menos nervaduras naturales que hay en Europa. No hay más que pueblo". Però, també per a ell, això no havia conduït al desenvolupament de la ciutadania $i$ d'alguna mena de responsabilitat col.lectiva, sinó a una reclusió sistemàtica dels individus respecte als afers públics, allò que el polític mallorquí va retratar amb el to del sarcasme: "Este es un pueblo que está en la plaza pública como las rameras añejas en su lecho. Ya no veo yo punto de apoyo para nada". L'edifici del liberalisme s'havia estabilitzat al preu d'inhibir l'opinió pública i això, com tornaria a raonar Silvela, passava elevades factures en una època de creixent mundialització econòmica i competència imperialista. Anys a ve- 


\section{El "desastre" del 98 i la crisi social de l'Estat liberal espanyol}

nir, aquest mecanisme mostraria ser impossible de superar per a tota mena de forces inclinades a regenerar el sistema. Fins i tot, crítics implacables d'aquest ordre de coses, com Joaquín Costa, Antoni Maura o Gumersindo de Azcárate, s'estimarien més arribar al poder convocats o reconeguts "des de dalt", que no haver de recórrer el camí incert de la mobilització i la lluita política dins la societat espanyola. Com es comprova també en determinats republicans, la mobilització contra el sistema podia desembocar en la conquesta d'una plataforma local estable que, un cop reconeguda, tendia a integrar-se sense competència en el pluralisme antidemocràtic del règim.

La comprovació d'aquest ordre de coses recurrent era allò que fomentava en els ambients més diversos, a parer meu, la consciència d'una Espanya desprovista de l'instrument polític mínim a l'altura dels temps. Segons crec, el problema no era ben bé que la Restauració imposara un concepte religiós i antiliberal d'Espanya com a nació, sinó, més aviat, que un ordre pluralista i antidemocràtic com aquell difícilment podia difondre de manera conseqüent cap concepte nacional de perfils mobilitzadors. Això hauria portat a l'exclusió dels socis del sistema, la complicitat dels quals assegurava la participació pròpia -de cadascun d'ells- en el poder. Així, doncs, 
liberals i republicans es veien obligats a ressuscitar periòdicament actituds anticlericals, sense acabar mai de ser conseqüents amb aquesta postura: el cèlebre article 11 de la Constitució arribaria sense reformes a 1923. Però també els conservadors com Cánovas, per la seua banda, havien d'allunyar-se del tipus de projecte oficial de nacionalització espanyola, tradicionalista i catòlica, d'un Menéndez Pelayo. Per a gran frustració dels promotors de la política catòlica, els seus amics conservadors es mostraven en aquest camp innegablement liberals.

Al capdavall, tots ells participaven d'un determinat liberalisme polític, que prioritzava l'autoreconeixement de les diverses "influències socials" i que feia d'això, al marge del foment de la participació cívica, l'única base viable d'estabilitat. La contrapartida era, com s'aniria comprovant, ofegar les possibilitats de tot projecte nacionalitzador espanyol capaç de mobilitzar la gent i demanar-li sacrificis, fos en el nom de la fidelitat al passat tradicional i a les seues glòries o en el nom d'un projecte progressista i laïc de futur. El problema de fons no era tant la d'una identitat espanyola obsoleta o reaccionària, sinó que el tipus de liberalisme imperant bloquejava l'expansió de tota iniciativa actualitzada en aquest terreny. 


\section{El "desastre" del 98 i la crisi social de l'Estat liberal espanyol}

Per dir-ho d'una altra manera, ni la mena de nacionalització de l'Alemanya del II Reich ni la de la III República francesa es mostraven compatibles amb l'Espanya de la Restauració. L'estabilitat liberal es comprovava contrària al dinamisme que es requeria. Per aquest camí, l'èxit de noves promocions de polítics populars -capaços d'engegar la dinàmica d'una mobilització efectiva- perdia sovint la seua inicial capacitat d'erosió sobre les tendències desmobilitzadores, que acabaven desacreditant el vell sistema canovista.

\section{L'expansió política dels nacionalismes alternatius}

Aquesta crisi de confiança en l'Estat de la Restauració suposava també qüestionar l'Estat que havia avançat en la sistematització de l'espai legal espanyol. El 1898 encara estava recent l'obra legislativa que havia dotat d'un marc comú aspectes fonamentals de la societat, com eren els codis civils $i$ de comerç. Quelcom de semblant succeia amb la qüestió dels furs bascos, abolits a l'inici de la Restauració a canvi d'introduir-hi el sistema del concert econòmic.

En tots dos casos, el que es comprova és l'existència d'una via específica i perllongada de desenvolupament del capitalisme, que posava l'accent en figures jurídiques i formes de cohesió social notablement diferenciades. En el cas de 
Catalunya, per exemple, val la pena destacar l'èmfasi en l'àmplia difusió dels vincles entre sectors molt diversos Principat que van fer els procuradors de les Corts de 1789 , en marcat contrast amb l'actitud dels valencians o dels delegats de Castella. La peculiar defensa d'una societat industrial, encabida dins dels gremis i l'hegemonia de la noblesa, tingué un representant pregon en Antoni de Capmany. Per últim, el món dels propietaris catalans es va mostrar enormement concialiador, a mitjan segle XIX, respecte a les demandes de respectar l'antic domini directe dels senyors com a un dret legítim de propietat, en oberta diferència, de nou, amb les opinions que dominaven llavors en les institucions agraristes valencianes.

Però també hi intervenien fenòmens d'identitat. És cert que el projecte liberal espanyol no havia tingut cap alternativa des de l'angle nacional en els seus orígens. Probablement, la consolidació heretada de la vella monarquia absoluta atorgava al projecte de l'Estat espanyol una solidesa ben considerable durant la major part del vuit-cents. A tot arreu, els liberals -com els carlins, al seu torn- s'entenien com a espanyols i era un projecte d'Espanya el que tractaren d'edificar. En la pràctica, però, el liberalisme català bastia aquest projecte a partir de referències històriques del seu propi àmbit. 


\section{El "desastre" del 98 i la crisi social de l'Estat liberal espanyol}

Allò que s'interpretava com a la lluita històrica dels catalans per les llibertats contra el despotisme -d'Olivares o de Felip d'Anjou- es relacionava ara amb la defensa de la llibertat constitucional. Tot plegat, es configurava una tradició política del catalanisme molt plural i oberta a diverses sensibilitats. Les discrepàncies polítiques amb els governs centrals, situats a la dreta, foren molt d'hora desqualificades per aquests poders com a signe d'un "separatisme", més o menys latent, que també es rescatava del passat històric, sobretot del 1640. El mateix liberalisme conservador català havia mostrat una adaptació difícil als criteris del moderantisme que predominava al conjunt d'Espanya. La preservació d'àmbits propis de representació d'interessos, enfront del dirigisme governamental dels centralistes, es manifestà com un desig ferm sota els governs moderats o conservadors. La defensa de normatives jurídiques molt arrelades dins les peculiars estructures del capitalisme català -allò que afectava directament el dret civil propi- va dificultar durant molt de temps la regulació definitiva d'un aspecte bàsic de l'Estat-nació.

El fet que tot això no adquirís durant dècades el protagonisme de les pugnes polítiques no pot restar entitat a aquests reptes reiterats. Reconèixer la seua existència, però, no equi- 
val a acceptar que aquests factors necessàriament estaven abocats a fonamentar un projecte d'identitat alternatiu. No eren uns referents capaços d'una única evolució, de manera que el clima creat en un panorama sociopolític i cultural concret va acabar sent decisiu en el seu rumb posterior. A partir d'una conjuntura determinada, al voltant del 98, acabarien de guanyar prou entitat com per a establir un nou escenari en la cohesió de l'Estat nacional espanyol.

En certa mesura, però d'una manera peculiar, uns fronts comparables o, potser, amb més entitat que a Catalunya, es donaven a les províncies basques. De nou, formes peculiars de desenvolupament del capitalisme coincidien ací amb un important substrat jurídic, amb una realitat lingüística diferent i, en especial, amb poderoses institucions pròpies del govern provincial. Des del 1839, la pau dins l'espai basc havia recolzat en un consens foral que va incloure, amb matisos, la major part dels liberals i dels carlins. Per a carlins com Alejandro Antuñano i per a liberals com Fidel de Sagarmínaga, la reivindicació d'un "àmbit polític intern" va semblar una premissa per a l'estabilitat de les províncies basques, justament a l'època culminant del centralisme moderat de mitjan segle XIX. 


\section{El "desastre" del 98 i la crisi social de l'Estat liberal espanyol}

En tots dos casos, la crisi del 1898, amb la seua càrrega de desprestigi per a l'obra política de la Restauració i per a les seues potencialitats de futur, va coindicir amb decisives transformacions internes, derivades de la ja perllongada industrialització catalana i de l'esclat de la indústria a Biscaia. Aquest fet, amb les seues conseqüències de noves formes massives de tensions socials, feia necessari recomposar el consens intern entre els sectors defensors de l'ordre. El 1898 havia fracassat aquell Estat espanyol que s'havia mostrat inflexible en la defensa de les colònies, com havien vingut reclamant les capes altes de la societat catalana, fins i tot en clara discrepància amb els corrents progressistes de Catalunya. L'Estat que assumia els interessos de l'élit colonial catalana va deixar d'acomplir una funció positiva el 1898. Més aviat, s'imposà la necessitat de prendre'n distàncies, recuperant si calia amb un més elevat contingut polític la història anterior de discrepàncies. La ineficàcia de l'Estat vençut no oferia grans avantatges per a consolidar l'ordre intern d'unes poblacions molt afectades pels problemes del capitalisme industrial. En aquest context, cercles intel.lectuals que venien considerant de temps enrere tot un seguit de problemes sobre la manera d'incloure Catalunya dins d'Espanya van trobar necessari definir amb uns passos més enllà la seua posició en el camp del catalanisme polític. També lla- 
vors aquesta oferta va trobar acollida en amplis cercles econòmics.

La mateixa pèrdua de legitimitat que derivava de la ineficàcia de l'Estat-nació -és a dir, de la mena de relacions que s'establien de manera duradora entre poder polític i societat civil i que venien reproduïnt-se des del 1875-, va conduir a una nova i gradual alineació de forces a la Biscaia industrial. Els vells greuges entre el liberalisme urbà i el tradicionalisme carlí van trobar la necessitat de superar-se, ara que creixia l'allau obrera i començava l'ascens del socialisme. La fòrmula de la reconciliació interna -i de la creació d'uns ideals capaços d'engegar esforços i il.lusions col.lectives- es definia enfront d'uns elements considerats aliens: l'obrerisme inmigrant i, en part, la idea d'una nació espanyola. L'alternativa era el paraigua integrador de la suposada recuperació d'un projecte polític autòcton.

D'una manera especial, moltes d'aquestes bases havien aparegut reiteradament durant la trajectoria de l'Estat nacional espanyol del vuit-cents. Ara, en el llindar del segle XX i sota l'impacte del fracàs de fons que implicava la derrota a Cuba i Filipines, aquest panorama va rebre una consideració política qualitativament nova. 


\section{El "desastre" del 98 i la crisi social de l'Estat liberal espanyol}

L'Espanya del 98 veia enfonsar-se, doncs, bona part del saldo que s'havia pogut fer d'aquell tancament de les escletxes internes que havien agitat la història del segle XIX. L'avanç indubtable en l'acceptació de les noves jerarquies socials i del pluralisme de les tradicions polítiques burgeses no va permetre una base ferma en el rellançament de la "nacionalització de les masses" per part del règim de la Restauració. Cap al 1898, els rèdits derivats de l'acceptació del marc espanyol als inicis del liberalisme i de la renovada inhibició de la ciutadania començaren a ser del tot insuficients per als nous temps que corrien. L'operació de consolidar un ordre social llargament qüestionat es mostrava fracassada en l'edifici polític que l'havia de garantir. Una intensa renovació de les jerarquies no havia estat capaç de coincidir amb l'estímul de l'espai polític i la ciutadania.

En aquestes circumstàncies, tot un seguit de tensions reiterades amb societats perifèriques, progressivament amenaçades en la seua estabilitat interna, adquiria una nova dimensió: valia la pena seguir dependent d'unes formes estatals que semblaven haver donat de sí tot el que calia esperar i que no es mostraven fàcilment adaptables als nous reptes? La visió de futur d'alguns polítics catalans i bascos Verdaguer i Callís, Prat de la Riba o Ramón de la Sota- trac- 
tà d'enllaçar amb un discurs tradicional i de caire corporatiu -de vegades, oposat als efectes de la societat industrial i del liberalisme-, per tal buscar un marc que garantira una nova cohesió interna, al marge d'aquella estabilitat desprestigiada i fictícia que s'identificava amb el desastre del 98.

\section{Conclusió}

Tot plegat, una determinada alternativa de construcció de l'Estat-nació espanyol, sota fòrmules liberals i socialment integradores i actualitzades, mostrava indicis d'esgotament i la seua renovació no es veia gens clara. Gairebé totes les qüestions que en aquest camp semblaven tancades podien considerar-se obertes de nou. Entre sectors creixents de la Catalunya del modernisme o del País Basc nacionalista, l'alternativa cultural, estètica i política no s'esperava tampoc d'una societat i d'un Estat unitari, atrapats en la teranyina d'un consens fictici i escassament dinàmic.

Amb això, el risc de trencar alguns consensos bàsics -d'haver d'exercir, per tant, l'exclusió política de bona part de la societat- s'apuntava en l'horitzó de qualsevol projecte alternatiu. El passat comú no oferia un mapa versemblant per al futur. 